\title{
中山間集落営農法人における放牧畜産の評価と課題
}

\author{
千田 雅之 1$) *$ ・渡部 博明 1$)$
}

\section{The Significance of Beef Cattle Breeding and Grazing on Paddies for Community- Based Group Farming and Improving Their Management}

\author{
Masayuki Senda $^{1) *}$ \& Hiroaki Watanabe ${ }^{1)}$
}

Community-based group farming is a pillar of regional agriculture in hilly and mountainous areas. Such farms mainly cultivate rice but face risks such as reduced revenue under rice price declines and a reduction in available farm labor. Beef cattle breeding and grazing on rice paddies should improve land utilization and profits of such farms. The authors examine the current management of cattle raising, feed production, and grazing. Most group farms appreciate that cattle breeding and grazing can use abandoned land and save management labor costs for small fields, but cattle raising is low in profit and requires intensive labor in the production of feed. Then, beef cattle breeders must increase their breeding skills, concentrate their fields, and reduce feed production costs.

キーワード：中山間, 集落営農, 水田, 肉用牛, 繁殖経営, 放牧

\section{1. はじめに}

集落営農法人は中山間地域の農業の担い手として 期待され，稲作中心の営農が行われているが，近年 の稲作収益低下のもとで事業の多角化に取り組む事 例が増えている. 他方, 食用米需要の減少する中で, 自給率の低い家畜飼料の増産をはかるため, 水田の 畜産利用の推進は重要であり, 小区画の水田戋場が 多く労衝力の限られる中山間地域に执いては, 放牧 を用いた家畜生産の展開が，水田の省力管理及び収 益確保の有効な方法として期待される. 水田放牧は, 山口県, 広島県などを中心に着実に増加しており, 近年は, 耕種経営や集落営農と連携した水田放牧や 集落営農自体が水田放牧を梃子に繁殖牛を飼養し始 める事例が増えている. 集落営農法人に上る繁殖牛 飼養は，全国的にその飼養頭数の減少が懸念される 中で, 子牛生産の新たな担い手としても期待される.

これまで, 集落営農法人の事業多角化の展開に関 して, 梅本 (2010) 等による組織論的観点から研究
が行われているが，その対象は農産加工や果樹や野 菜作であり，農地活用を含む畜産利用による事業展 開の可能性に論究した研究は行われていない。また， 肉用牛繁殖経営に打沙放牧の評価研究に関して は，千田（2008）等があるが，集落営農法人に打け る水田放牧の実態やその評価研究は行われていない.

したがって家畜飼養経験の無い稲作中心の集落営 農法人に扮いて, 繁殖牛の放牧飼養を前提と寸る子 牛生産が円滑に行われるかぞらかについては不明点 が多く，その評価や今後の展望について以下の点等 について検証すべきと考光る. (1)中山間の集落営農 法人に沶いて放牧畜産はどのように評価されている のか，(2)その子牛生産は慣行飼養と比べて低コスト であり収益性は高いのか, (3)稲作収益の低下するな かで，放牧畜産の収益向上を図り，集落営農の基幹 部門に発展するらえでの課題は何か，等である.

本研究では, 稲作と肉用牛の複合経営を営む集落 営農法人を対象に，放牧畜産の実態を生産管理面か

\footnotetext{
1) 農業・食品産業技術総合研究機構近畿中国四国農業研究センター; NARO Western Region Agricultural Research Center 
表 1. 放牧畜産導入法人の概要（広島県三次市）

\begin{tabular}{|c|c|c|c|c|c|c|c|c|c|c|}
\hline \multirow{2}{*}{$\begin{array}{c}\text { 法人番号 } \\
\text { (放牧開始年) }\end{array}$} & \multirow{2}{*}{ 繁殖牛頭数 } & \multirow{2}{*}{$\begin{array}{c}\text { 経営面積 } \\
\text { (ha) }\end{array}$} & \multicolumn{3}{|c|}{ 主な作目と作付面積（ha） } & \multicolumn{2}{|c|}{ 放牧面積（ha） } & \multirow{2}{*}{$\begin{array}{l}\text { 解消された } \\
\text { 遊休地 (ha) }\end{array}$} & \multirow{2}{*}{ 子牛出荷月齢 } & \multirow{2}{*}{$\begin{array}{l}\text { 今後の } \\
\text { 意向 }\end{array}$} \\
\hline & & & 水稲 & 牧草 & その他 & 転作田 & 水稲裏作 & & & \\
\hline 1 (2008) & $12[4]$ & 66.0 & 42.0 & 6.8 & 稲 WCS & 2.2 & \multirow[t]{2}{*}{2.0} & 2.2 & 8 か月 & 維持 \\
\hline 2 (2011) & $12[3]$ & 67.8 & 53.0 & 5.2 & 稲 WCS & 5.2 & & 5.0 & 2 か月 & 維持 \\
\hline 3 (2007) & $12(4)$ & 34.0 & 23.0 & 3.9 & 野菜 & 3.0 & \multirow{4}{*}{$\begin{array}{l}3.8 \\
3.5\end{array}$} & 4.5 & 1 か月 & 増頭 \\
\hline 4(2009) & 8 & 29.0 & 18.0 & 4.0 & 野菜 & 2.0 & & 3.0 & 8 か月 & 増頭 \\
\hline $5(2012)$ & 3 & 15.0 & 6.7 & 1.5 & 稲 WCS & 1.4 & & 0.4 & 1 か月 & 維持 \\
\hline $6(2004)$ & $0[4]$ & 27.9 & 15.7 & 3.4 & 大豆・野菜 & 1.7 & & 1.7 & なし & \multirow[t]{2}{*}{ 維持 } \\
\hline 7 (2012) & $0[8]$ & 30.0 & 22.7 & 1.4 & 大豆・野菜 & 0.8 & 0.2 & 1.4 & なし & \\
\hline 平均 & $6.7[2.7]$ & 38.5 & 25.9 & 3.7 & & 2.3 & 1.4 & 2.6 & & \\
\hline \multicolumn{9}{|c|}{ 三次市以外の放牧実施は 16 法人, 繁殖牛保有頭数 $1 \sim 22$ 頭（平均 7.7 頭). } & & \\
\hline
\end{tabular}

1）繁殖牛頭数は保有頭数. [ ] は借入頭数，（）は貸出頭数. 広島県北部畜産技術指導所及び筆者調査.

ら明らかにするとともに，作業労働の内容と時間及 び収益性を分析し，改善に向けた課題を検討する.

\section{2. 集落営農法人による放牧畜産の評価}

まず，アンケート調査から，集落営農法人に打け る放牧畜産の位置づけと評価, 問題点を把握する. 広島県では 23 の集落営農法人が水田放牧を行って いる. 三次市には集落営農法人が 22 組織存在する が，2004 年以降に 7 法人が水田放牧を開始し，内 5 法人は繁殖牛を自己資金で購入し保有する。また， 3 番の法人は他法人に牛を貸し出し， $1,2 ， 6 ， 7$ 番 の法人は構成員や他の経営から牛を借り入れる (表 1).

7 法人の平均経営面積は約 39 ha，その流とんどが 水田であり水稲作付面積は約 26 ha である. 転作作 物は牧草が多くその作付面積は平均 3.7 ha である. 繁殖牛の保有頭数と借入頭数の合計 9.4 頭で除する と $40 \mathrm{a}$ /頭であり，牛の粗飼料は注ぼ自給されている と考光られる。転作田の放牧面積は 2.3 ha であり放 牧後に解消された遊休地の面積にほぼ等しい。この ほかに 4 法人が水稲裏作で放牧を行う。牛の飼養管 理は 3 番と 5 番の 2 法人が輪番で行い 5 法人は特定 の構成員に委衫ている. 生産物の子牛は, 3 法人が 生後 $1 \sim 2$ か月齢で市場販売する.

放牧導入の効果について尋ねたところ，7 法人が 「耕作放棄・保全管理田の解消」, 5 法人が「小区画・ 広畦畔圃場の管理作業の軽減」を評価している。しか し,「法人の収益増加」,「地域の活力向上」の回答は
3 法人,「獣害の軽減」,「就労機会の拡大」の回答は, 2 法人,「経営面積の拡大」の回答は 1 法人にとぞま る。な报，これらの回答数は放牧開始の目的に注 等しく所期の効果は得られている（表 2).

他方，放牧畜産実施上の問題点では，子牛生産を 行う5 法人すべてが「子牛の流産等の事故」を回答 し, 3 法人が「牛舎での飼養管理の負担」,「舎飼牛の 飼料確保」を回答している。また 4 法人が「季節によ

表 2. 放牧畜産導入の効果と問題点

\begin{tabular}{l|c|c}
\hline \hline \multicolumn{1}{c|}{ (放牧導入の効果) } & 回答数 & 割合 $(\%)$ \\
\hline 耕作放棄·保全管理田の解消 & $7(6)$ & 100 \\
小区画·広畦畔戋場の管理軽減 & $5(4)$ & 71 \\
地域の活力向上 & 3 & 43 \\
法人の収益増加 & 2 & 43 \\
構成員の就労機会の拡大 & $2(2)$ & 29 \\
獣害の軽減 & 1 & 29 \\
経営面積の拡大 & 5 & 14 \\
\hline (放牧畜産実施上の問題点) & 3 & 60 \\
\hline 子牛の流産等の事故 & 3 & 60 \\
舎飼牛の飼料確保 & 4 & 57 \\
牛舎での飼養管理 & 3 & 43 \\
季節による牧草の過不足 & 3 & 43 \\
放牧牛の捕獲・移動 & 2 & 29 \\
固場の硬度化·耕起作業 & 1 & 14 \\
獣害の拡大 & 0 & 0 \\
畦畔の崩壊 & 給水等の放牧管理負担 & \\
\hline
\end{tabular}

1）表 1 の 7 法人の調査（2013 年 8 月実施）による.（） 内は放牧開始の目的に対する回答数. 
る牧草の過不足」を，3法人が「放牧牛の捕獲・移 動」,「圃場の硬度化・耕起作業の負担増」を回答して いる。また，牧草地のシカ侵入など「獣害の拡大」を 回答した法人もある.

総じて言えば，遊休農地の解消や畦畔除草を含め 小圃場管理の省力化については評価しているが，家 畜の生産販売を通じた法人収益の増加はさほど顕者 ではなく，牛の事故や飼養管理の負担，飼料の確保 に課題をかかえている状況がらかがえる. そこで, 構成員に畜産農家が存在せず輪番で家畜管理を行ら 3 番の $\mathrm{K}$ 法人を対象に, 家畜生産管理, 作業労働, 収益の実態を詳しく見ていく.

\section{K 法人における放牧畜産の実態}

\section{(1) K 法人の営農概要}

$\mathrm{K}$ 法人は構成員 34 名で 2002 年に設立された. 農 繁期の臨時雇いを含め農業労働力は多いが， ほとん ぞは高齢者である. 経営耕地 33 ha のらち水張り面 積は 27.4 ha で畦畔や道路法面が多い. 水稲作付圃場 は 23 ha で，集落の中心部を流れる河川沿いの基盤 整理された場所に位置するが，一筆当たり平均面積 は 13.5 a である。このらち 378 a は裏作に牧草を栽 培し放牧利用寸る。山沿いの水田圃場 $390 \mathrm{a}$ は, 平 均面積約 5 a と小さく, 転作田として牧草を栽培し, らち $295 \mathrm{a}$ は畦畔管理も含めて主に放牧利用する. このほか，構成員の就労機会確保のため $61 \mathrm{a} て ゙$ 多種 類の野菜栽培を行ら（表 3 ).

\section{表 3. K 集落営農法人の経営概要 (2013 年)}

\begin{tabular}{|c|c|}
\hline 概要 & 2002 年設立（設立時 : 構成員 34 名, 26 ha） \\
\hline 労働力 & 24 人（平均年齢 68 歳, 農業従事日数 56 日) \\
\hline 経営耕 & $\begin{array}{l}\text { 田 } 33 \text { ha（水張り面積 } 27.5 \text { ha，構成員外 } 5.9 \\
\text { ha）(地代 } 13 \text { 千円 } 10 \mathrm{a} \text {, 構成員外 } 10 \text { 千円/10 a) }\end{array}$ \\
\hline 家畜 & 繁殖牛 12 頭. 子牛は 1 か月齢販売 \\
\hline \multirow{3}{*}{$\begin{array}{l}\text { 作目・ } \\
\text { 作付面積等 }\end{array}$} & $\begin{array}{l}\text { 水稲 } 23 \mathrm{ha} \text { (食用米 } 9.5 \text { ha, 酒造好適米 } 12.5 \text { ha } \\
\text { 等, } 13.5 \mathrm{a} \text { /筆), 内 } 378 \mathrm{a} \text { は二毛作 (冬作牧草) }\end{array}$ \\
\hline & 牧草 $390 \mathrm{a}$ （放牧用 $295 \mathrm{a}$, 採草用 $95 \mathrm{a}, 5 \mathrm{a} /$ 筆） \\
\hline & 野菜 $61 \mathrm{a}$ (汇うれん草, 小松菜, 玉葱等） \\
\hline 主施設 & 事務所, 作業所, 野菜八ウス, 簡易畜舎 \\
\hline 主な機械 & $\begin{array}{l}\text { コンバイン, 田植機, 動噴, 小型ロールベー } \\
\text { ラー, 小型ラップ機, フレールモア, 畔塗機 }\end{array}$ \\
\hline 経営間連携 & $\begin{array}{l}\text { 圑場耕起（@4 千円/10 a)，水管理（@9 } \\
\text { 円)，畦畔管理（同）の構成員へ委託. 米の } \\
\text { 乾燥調製は JA 委託. 他法人に繁殖牛を貸与 }\end{array}$ \\
\hline
\end{tabular}

水稲はすべて移植栽培で，5月上旬から下旬にか けて食用米のコシヒカリ, 酒造好適米の八反 35 号, 八反錦，千本錦，食用米の新千本の順に田植えを行 5. 耕起作業の多くは構成員に 4,000 円/10 a で委託 する。水管理および畦畔除草も構成員にそれぞれ 9,000 円/10 a で委託するが，管理の困難な構成員が 増えつつあり，法人自ら管理する圃場も少なくない. 收穫は 9 月下旬から 10 月下旬にかけて行らが乾燥 調製はJAに委託する。単収はいずれも $540 \mathrm{~kg} / 10 \mathrm{a}$ 前後である. 24 年産の販売単価（精算額）は，食用 米のコシヒカリ 1 等の $60 \mathrm{~kg}$ あたり 14,560 円，新千 本 1 等の 13,140 円に対して, 酒造好適米の八反錦は 15,780 円と高く, 近年酒造好適米の作付を増やして きている，董作放牧を行わない田には牛ふん堆肥を $1.2 \mathrm{t} / 10 \mathrm{a}$ 施用し, 基肥に加えて追肥やミネラル施用 も行らなど水稲の肥培管理は充実している.

ただし，25年産米の概算金はいずれも 24 年産よ り $60 \mathrm{~kg}$ あたり 2,000 円， 26 年産はさらに 2,200 円 ～2,600 円も低下して打り，米の直接支払交付金も 半減することから水稲収益は減少傾向にある.

\section{（2）家畜生産管理}

$\mathrm{K}$ 法人は設立後，転作対応と収益確保のため小区 画圃場ではアスパラガスや大豆生産に取り組んだが 失敗し保全管理で対応していた，その後，除草経費 や地代捻出の可能な収益部門を模索するなかで，放 牧畜産に興味をもち，2007 年に経産の妊娠牛 5 頭を 自己資金で導入し家畜生産に着手している.

法人設立時, 構成員に牛飼養者はいなかったため, 牛の飼養管理は 6 名（平均年齢 74 歳）が週交替で 対応している. 全頭舎飼の 12 月から 3 月上旬は給 飭・給水・掃除等に朝夕あわせて 3 時間，放牧期間 中は放牧牛の観察を含めて 1 日 2 時間をかけてい る.この飼養管理の対価は繁殖牛 10 頭までは 1 日 2,000 円， 1 頭増えるごとに 150 円加算される.

放牧期間は 3 月中旬から 12 月上旬までであるが, 出産予定日の 1 か月前（妊娠末期）から出産後 1 か 月後（授乳期）まではこの期間でも簡易牛舎で飼養 する。尒牛は育成技術等を要することから行わず, 生後 1 か月歯で親牛から離乳し市場で販売する。離 乳後, 捕獲の容易な親牛は牛舎から離れた圃場に移 動して放牧飼養する。授精は可動式の保定枠を放牧 地に持ら込及発情牛を捕獲・保定して行ら。捕獲困 
難な個体は牛舎続きの圃場に放牧し，妊娠確認後, 近くの固場へ移動して放牧する.

放牧中は放牧草以外の飼料は匡とんど与えない. 3 月中旬から 4 月下旬， 11 月上旬から 12 月上旬は 水稲裏作圃場で放牧し，5月～10 月は転作田を中心 に放牧する。水稲裏作の牧草栽培は，水稲収穫の 2 週間前に早生種のイタリアングラスを播種し，水稲 収穫後に稲わらを収穫し化成肥料を $20 \mathrm{~kg} / 10 \mathrm{a}$ 施用 する。诗，気温の上昇し始める 2 月に $20 \mathrm{~kg}$ の追 肥を行う。転作田の牧草は放牧を終えた圃場から, 10 月に普通種のイタリアンライグラスを不耕起状態 で播種し，同時に $20 \mathrm{~kg}$ の施肥を行ら．6月～7 月に 残草をフレールモアで掃除刚りした後, ミレットを 不耕起で播種し $20 \mathrm{~kg}$ の施肥を行ら。転作田の放牧 固場は牛舎近くに約 $130 \mathrm{a}$, 約 $1 \sim 2 \mathrm{~km}$ 離れた場所 に 5 団地 $(18 \sim 60 \mathrm{a})$ 存在する.

採草地の栽培管理も同様であるが，5月から 9 月 にかけて 4 回採草を行ら。収穫調製は小型ロールベ ール体系でサイレージ調製する. この作業は $3 \sim 4$ 人 で行っており，25 kg 前後のベールを素手で持ち運 ぶなど労働時間と負荷の大きい作業となっている.

2013 年の放牧のべ頭数は 1,872 日頭，繁殖牛 1 頭 あたり平均 165 日であり，妊娠確認牛のみ放牧する 事例と比べて比較的長い。 また，466日は法人外で 預託放牧するため $\mathrm{K}$ 法人の管理戋場での放牧は 1,406 日頭である. 水稲裏作と併せた放牧地 673 a で 除すると $10 \mathrm{a}$ あたり放牧のべ頭数は 21 日頭と少な い. 牧草播種や施肥が十分に行われているにもかか わらず，牧草が放牧に十分活用されていないことが 推察される.

（3）作業労働からみた繁殖部門の位置づけと課題

$\mathrm{K}$ 法人の年間の農作業労働は約 10,750 時間（構成 員委託作業を含む）で，部門別の割合は水稲 59\%, 野菜 $22 \%$, 畜産 $18 \%$ の順に多い. この 3 部門の作 業労働時間を月別に見ると（図 1)，4月から9月が 多い。これは水稲作中心の営農であることによる。 これに対して，野菜と畜産は年間を通じて作業のあ ることが見てとれる．現在は高齢の構成員の臨時雇 いで対応可能であるが，近い将来 3 人 5 人程度の 専従者で営農を行わざるを得なくなる状況を想定す ると農作業労働の平準化は解決しなければならない 課題である。

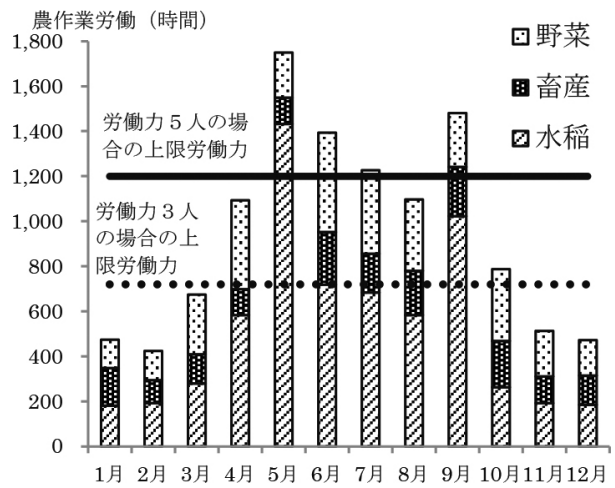

図 1. 部門別月別作業労働（2013 年, K 法人)

水稲の作業労働は乾燥調製作業を除いても 10 a あ たり 25.8 時間（構成員への委託作業を含む）であ り，生産費統計による中国地域 5 ha 以上の経営の 17.1 時間よりも多い。このらち水管理や畦畔除草が 10 a あたり 9.8 時間と多く, 法人に委託する固場が 増える傾向にあり今後大きな負担となることが予想 される。また，獣害予防のためのネット等の設置に 1.4 時間を要しておりこの軽減も課題である.

表 4 は，畜産部門の作業労働時間を集計したもの である．年間 1,896 時間が費やされており，就労時 間面では 1 人分の就労機会が形成されている. しか し，成牛 1 頭あたり作業労働時間は 158 時間と統計 值よりも多い. 放牧飼養し子牛育成を行わないにも かかわらず，飼養管理作業が意外に多いのは分散す る放牧地で飼養する牛の見回りや牛舎での給慨や排

表 4. 畜産部門の作業労働時間

(時間)

\begin{tabular}{c|c|c|c|c}
\hline \hline \multirow{2}{*}{ 作業項目 } & \multicolumn{2}{|c|}{ K 法人 } & \multicolumn{2}{c}{ 生産費 $(2012$ 年 $)$} \\
\cline { 4 - 5 } & 畜産全体 & \multirow{2}{*}{ 1頭あたり } & \multicolumn{2}{|c}{1 頭あたり } \\
\cline { 4 - 5 } & & & $10-20$ 頭 & 中国地域 \\
\hline 飼養管理 & 881 & 73 & 80 & 105 \\
飼料生産 & 681 & 57 & 24 & 21 \\
放牧管理 & 230 & 19 & 8 & 9 \\
その他 & 104 & 9 & 10 & 10 \\
\hline 計 & 1,896 & 158 & 121 & 145 \\
\hline
\end{tabular}

1）生産費統計は計算期間を 1 年に換算して示す。飼養管理 は給餌, 排せつ物処理, 授精や診療立ち会い, 放牧牛の見 回りを含む. 放牧管理は牧柵の移設, 牛の移動に関わる作 業を集計. 
表 5. K 法人の牧草生産コスト

(円/10 a)

\begin{tabular}{|c|c|c|c|}
\hline 費目等 & $\mathrm{K}$ 法人 & $\mathrm{S}$ 牧場 & 備考（K 法人） \\
\hline 牧草種子代 & 5,077 & 810 & IR $3 \mathrm{~kg}$, MI $3.5 \mathrm{~kg}$ \\
\hline 肥料代 & 5,370 & 7,776 & 3 回施肥 \\
\hline 梱包資材 & 29,816 & 6,534 & ラップ等 \\
\hline 機械償却費 & 11,186 & 43,864 & 小型ベール体系 \\
\hline 労働費 & 48,611 & 6,300 & 労賃 1,000 円/時 \\
\hline 計 & 100,060 & 65,284 & \\
\hline 単収（乾物 $\mathrm{kg} / 10 \mathrm{a} ）$ & 1,100 & 1,650 & \\
\hline 生産コスト（円/kg） & 91 & 40 & \\
\hline
\end{tabular}

1） $\mathrm{K}$ 法人および $\mathrm{S}$ 牧場（茨城県）の畜産部門元帳，作業日 誌より集計. K 法人は堆肥散布なし。ベール乾物重量を 15 $\mathrm{kg} /$ 個として計算.

せつ物処理作業が少なくないことによるまた，飼 料生産作業で最も多いのは，牧草の収穫・運搬であ り $95 \mathrm{a}$ の作業に 464 時間も要している. この原因は 小区画圃場に拈ける小型ベール体系での収穫調製運 搬作業による。さらに牧柵の移設，牛の移動など放 牧管理作業も少なくない.

そこで，K 法人の牧草生産コストを試算すると， $10 \mathrm{a}$ あたり約 10 万円，乾物 $1 \mathrm{~kg}$ あたり 91 円と計算 される (表 5)。大型ベール体系で採草する茨城県の $\mathrm{S}$ 牧場の事例と比べて，梱包資材や労働費が非常に 高い点が指摘される. 労働費は地元に還元される部 分であるが，今後，労働力の確保が困難になること も予想されるため, 外部からの稲 WCS や牧草の購 入，或いは中型ロールベール体系による牧草収穫作 業の省力化が必要と考えられる.

\section{（4）収益面から見た畜産の評価と課題}

表 6 は K 法人の収益構造を部門別に分析したもの である．売上高，経常利益ともに稲作が大きな割合 を占める。また，稲作は製造費のらち労務費や構成 員への作業委託費，地代など地元に還元される金額 も大きい，畜産の売上高は製造費を下回り営業損失 が大きいが，戦略作物助成，耕畜連携助成等の経営 所得安定対策の交付金が多いため，経常利益が確保 されている．労務費等の地元還元額と経常利益を合 わせると約 280 万円となり，常雇一人を雇える付加 価値が形成されている. 野菜では地元に還元される 労務費は多いが売上高はそれより少なく，補助金を 加えた経常利益は赤字である.

深刻な点は, 稲作部門の 25 年度売上高は米価下落
表 $6 . \mathrm{K}$ 法人の収益構造

\begin{tabular}{l|c|c|c|c}
\hline \hline & 水稲 & 畜産 & 野菜 & 合計 \\
\hline 売上高 & $\begin{array}{c}28,575 \\
(23,375)\end{array}$ & 2,445 & 1,641 & 35,116 \\
& & & $(29,916)$ \\
\hline 製造費用 & 27,785 & 5,221 & 3,222 & 39,806 \\
内労務費 & 4,082 & 1,690 & 2,321 & 10,600 \\
内委託費 & 4,852 & 28 & & 5,950 \\
内地代 & 2,858 & 488 & 79 & 3,425 \\
販管費 & & & & 4,666 \\
営業利益 & 789 & $\mathbf{\Delta} 2,776$ & $\mathbf{\Delta} 1,581$ & $\mathbf{\Delta} 9,356$ \\
& $(\mathbf{\Delta} 4,411)$ & & & $(\mathbf{\Delta} 14,556)$ \\
\hline 営業外収支 & 3,450 & 3,366 & 214 & 11,553 \\
& $(1,725)$ & & & \\
\hline 経常利益 & 4,239 & 591 & $\mathbf{\Delta} 1,368$ & 2,196 \\
& $(\mathbf{\Delta} 2,986)$ & & & $(\mathbf{\Delta} 4,729)$ \\
\hline
\end{tabular}

1）労務費は実労報酬で単価は機械作業 1200 円/時，一般作 業 800 円. 合計にはその他の売上や一般管理費，追加労務 費等を含む。（）は 2014 年産米の概算金，米の直接支払 い交付金に基づく 2014 年の試算値. K 法人総会資料（2013 年度), 部門元帳より集計.

により前年より約 400 万円減少し，26 年度はさらに 500 万円以上減少すると見込まれることである. 加 えて米の直接支払交付金も削減されるなど稲作部門 の収益は確実に減少傾向に推移している．稲作以外 の収益向上が課題であるが，上述のよらに野菜部門 の収益もすでに赤字である.

そこで，畜産部門による収益向上の可能性を探る ため，その収益構造を詳しく見ておく（表 7). K 法 人は子牛を生後 1 か月齢で販売するため，単価は 1 頭あたり 239 千円と 8 か月齢の子牛の市場平均価格 より約 26 万円低い. 1 頭あたり費用を統計值と比べ ると, 種代・種付料, 自給飼料費, 牛の減価償却費 が多い. 種代・種付料は受胎までの種付回数が平均 2 回と多いこと, 自給飼料費は小型ロールベール体 系による収穫, 牛の償却費は妊娠牛を導入するなど 費用の多さは技術に起因する. 現在飼養する繁殖牛 12 頭の産歴をみると 44 産中 4 度の死産があり，正 常産の平均分娩間隔は394 日と長い. 死産の原因は 明らかにされていないが，分婏間隔の長さは発情の 見逃しや適期の授精が行われていない可能性が推察 される。また，購入飼料費は子牛育成をしないため 統計值より少ないが，親牛 1 頭の購入飼料（すべて 濃厚飼料）は 3 万円以上と多い. 
表 7. 繁殖牛 1 頭あたり収支

（円）

\begin{tabular}{|c|c|c|}
\hline 項目 & $\mathrm{K}$ 法人 & 統計値 \\
\hline 売上高計 & 216,139 & 359,033 \\
\hline 子牛 & 191,473 & \\
\hline 経産牛 & 12,307 & \\
\hline 牛貸出料 & 12,359 & \\
\hline 製造費用計 & 461,501 & 440,593 \\
\hline 種代 - 種付料 & 28,129 & 15,063 \\
\hline 診療衛生費 & 6,803 & 16,254 \\
\hline 自給飼料資材 & 85,725 & 52,673 \\
\hline 購入飼料 & 33,844 & 112,239 \\
\hline 牛償却費 & 78,573 & 54,471 \\
\hline 機械施設償却費 & 7,458 & 14,019 \\
\hline 同上購入修繕費 & 9,842 & 9,819 \\
\hline 子牛検査·親牛削蹄 & 7,329 & 9,489 \\
\hline 諸材料費添か & 8,831 & 13,823 \\
\hline 労務費·構成員賃料 & 151,872 & 142,743 \\
\hline 地代支払い & 43,096 & \\
\hline 営業収支 & $\mathbf{\Delta} 245,363$ & $\mathbf{\Delta} 81,560$ \\
\hline
\end{tabular}

1）統計值は，平成 24 年度子牛生産費（計算期間 1.2 年） を 1 年に換算して掲載. $\mathrm{K}$ 法人畜産部門元帳，農林水産省 「子牛生産費」より作成.

\section{4. おわりに一畜産収益改善の課題一}

集落営農法人では，米価及び稲作収益低下のもと で基幹部門の食用米に替わる営農部門の導入・拡大 が必要である，他方，法人の農作業従事者が高齢化 乙年々減少するなかでは，農作業の季節的偏在の顕 著な稲作（飼料用米や酒造好適米を含む）では法人 の管理面積に限界が生じる。このため，専従者体制 による放牧畜産中心の営農展開も期待される。

そこで，集落営農法人に和ける現行の放牧畜産の 実態を分析した結果，以下の点が明らかにされた。 (1)放牧や採草は耕作放棄圃場や小区画圃場で行われ て打り, 放牧畜産が遊休地の解消, 小耕地の管理作 業軽減に寄与していることは評価されている。 (2)し かし，畜産物による収益性は低く，転作に伴ら交付 金で畜産部門の収益が確保されている。 (3) その理由 は家畜の生産性（繁殖率）が低いこと，種代や粗飼 料生産に要する費用が多いこと，作業労働が多いこ
とによる. (4)繁殖率の低さは分散する放牧地で短い 巡回の際に発情確認を行うため, 発情の見逃しや適 期授精が行われていない可能性が推察される. (5)費 用の多さは, 種付回数が多いこと, 牧草生産にかか る資材費が多いことによる。(6)作業労働の多さは, 授乳牛をはじめ牛の飼養管理, 牧草の収穫運搬, 放 牧管理作業が多いこと，それは，12 頭の牛を分散す る放牧地で飼養していること，小型ベール体系での 牧草收檴作業を行らことに起因する。

こうした問題を解決し，畜産部門を中心に集落営 農法人の収益向上を図るためには，以下の対応が必 要と考兄る. (1)牛の移動や採草飼料の運搬作業を低 減し，牛の十分な観察時間を確保するため，集落外 縁部に分散する小圃場の畜産利用から，畜舎から近 い場所倸草放牧地を集積する等，集落営農全体の 围場利用のレイアウトを見直す，(2)スンチョンを 活用した牛の管理と子牛育成技術を習得し生産物の 付加価値を高める，(3)採草は中型ベール体系による 收穫が可能な整備田等で行う, (4)暖地型永年生牧草 を導入し，放牧草の管理費用を削減する，(5)飼料イ ネ等を利用して放牧期間の延長を図る等である。

また，観察や飼養管理作業，粗飼料生産作業の効 率，コスト低減の観点から，飼養頭数についても検 討が必要である．今後，こらした対応により，限ら れた労働力で地域の水田を管理し，かつ稲作以上の 收益確保が可能であるかどらか効果を試算し，現地 法人に示し，実証する予定である.

\section{付記}

本稿は科研費基盤研究（C）（25450340）による成 果の一部である.

\section{引用文献}

梅本 雅（2010）「水田活用によるコミュニティビジネスの展 開と技術課題」谷口信和・梅本雅・千田雅之・季侖美『水 田活用新時代』農山漁村文化協会, 181-210.

千田雅之（2008）「北関東中間地帯に打ける水田放牧の経営評 価」『農林業問題研究』44(1), 228-233. 